\title{
Effect of Potassium on Sol-Gel Cerium and Lanthanum Oxide Catalysis for Soot Combustion
}

\author{
Daniela Salinas $^{1 *}$, Gina Pecchi ${ }^{1}$, Vicente Rodríguez ${ }^{1}$, José Luis García Fierro² \\ ${ }^{1}$ Department of Physical Chemistry, Faculty of Sciences, University of Concepcion, Concepcion, Chile \\ ${ }^{2}$ Institute of Catalysis and Petrochemistry, ICP-CSIC, Cantoblanco, Madrid, Spain \\ Email: $\underline{\text { dasalinas@udec.cl }}$
}

Received 4 June 2015; accepted 13 July 2015; published 17 July 2015

Copyright (C) 2015 by authors and Scientific Research Publishing Inc.

This work is licensed under the Creative Commons Attribution International License (CC BY). http://creativecommons.org/licenses/by/4.0/

c) (i) Open Access

\begin{abstract}
The catalytic activity in the soot combustion is reported for a series of potassium-promoter alumina supported catalysts prepared by the sol-gel method to be used in the catalytic combustion of soot. The studied systems correspond to $\mathrm{CeO}_{2}-\mathrm{Al}_{2} \mathrm{O}_{3}$ and $\mathrm{La}_{2} \mathrm{O}_{3}-\mathrm{Al}_{2} \mathrm{O}_{3}$ with charges of 3 and 5 wt\% of $\mathrm{CeO}_{2}$ and $\mathrm{La}_{2} \mathrm{O}_{3}$. Potassium impregnation is performed to reach 3 atoms of $\mathrm{K}$ per $\mathrm{nm}^{2}$ of the mixed oxide. The effect of the potassium incorporation increases its reducibility, decreases the surface area and forms a new type of oxygen that is stronger than the oxygen in mixed oxides with similar chemical nature. The existence of potassium oxides, $\mathrm{K}_{2} \mathrm{O}$ and oxygen responsible for the vacancies and/or lattice defects $\left(0^{2-}\right)$ are related to good catalytic activity. Additionally, the presence of alkali affects the structural and textural characteristics of the catalyst, promoting the catalytic activity in soot combustion.
\end{abstract}

\section{Keywords}

Sol-Gel, Potassium, Cerium, Lanthanum, Soot Combustion

\section{Introduction}

It is generally known that in the oxidation of hydrocarbons, the volatile organic compounds (VOCs), the particulate matter such as soot, and the emission of $\mathrm{NO}_{\mathrm{x}}$ species into the atmosphere are harmful to people and environment [1]. An alternative for the control of these species is catalytic combustion [2]-[8]. The stabilization of the emission levels of these materials is increasingly strict, and new catalysts have been developed to meet the requirements of these new technologies. Soot is a particulate material resulting from the incomplete combustion ${ }^{*}$ Corresponding author. 
of diesel fuel that remains in the filters of vehicle engines, causing serious health problems [9]. An alternative is to burn this particulate material [7] [9]. The catalyst deposited in the ceramic filters could oxidize the soot, reducing its emission into the atmosphere. However, the temperatures at which the gases emitted into the atmosphere are cooled between $300^{\circ} \mathrm{C}$ and $400^{\circ} \mathrm{C}$, coal is burned at temperatures that range between $500^{\circ} \mathrm{C}$ and $600^{\circ} \mathrm{C}$. Therefore, the catalysts used in the catalytic combustion of soot must be capable of presenting catalyst activity at low temperatures [10].

An important number of catalytic formulations have been developed in this field, including oxides [11]-[14], perovskites [9] [15]-[17], spinels [18] and metals [19]. The range of metals refers to the use of noble metals [20] which are not favorable for commercial use due to their high cost. However, metallic oxides [21]-[23] used as catalysts are more favorable as the atomic number of the metal increases because of the promotion effect with alkali materials [24]. Additionally, $\mathrm{K}^{+}$could lower the unsaturation of oxide anion coordination and the mobility of atoms. It is well known that the catalytic combustion of soot is favored by basic catalysts [24]; thus, to enhance the catalytic properties of K-supported catalysts, the addition of $\mathrm{CeO}_{2}$ and $\mathrm{La}_{2} \mathrm{O}_{3}$ is proposed to improve and enhance the catalytic activity of the support metal oxides.

The catalysts in this study have been impregnated with potassium. Additionally, the thermal stability, redox properties and wide application of metallic oxides are widely recognized. The incorporation of two metals into the oxide allows materials to be generated with different structural and electronic properties [25]. Within these properties, the morphological and valence changes are highlighted, as well as possible vacancies that originate in the material or the change in the chemical nature of the elements. $\mathrm{CeO}_{2}$ has been considered because of its redox properties and its great affinity for the adsorption of oxygen [26]-[28], which could favor the basic characteristics of the catalyst. Furthermore, the great capacity of the cerium to admit modifications in both the surface and in the bulk of the material is also highlighted. $\mathrm{La}_{2} \mathrm{O}_{3}$ has been chosen because of its recognized thermal stability, and the presence of $\mathrm{La}^{3+}$ confers a basic character to the catalyst. The aim of this work is to study the different effects produced when $\mathrm{K}$ is supported on two different mixed oxides: $\mathrm{CeO}_{2} / \mathrm{Al}_{2} \mathrm{O}_{3}$ and $\mathrm{La}_{2} \mathrm{O}_{3} / \mathrm{Al}_{2} \mathrm{O}_{3}$. The samples are prepared by the co-gelation of the catalyst precursors to avoid sintering and the induction of a stronger interaction between the oxides.

\section{Experimental Analysis}

\subsection{Preparation}

The sol-gel $\mathrm{La}_{2} \mathrm{O}_{3}-\mathrm{Al}_{2} \mathrm{O}_{3}$ and $\mathrm{CeO}_{2}-\mathrm{Al}_{2} \mathrm{O}_{3}$ mixed oxides were prepared using tri-sec-aluminum butoxide and the corresponding acetylacetonates of cerium and lanthanum to achieve 3 and $5 \mathrm{wt} \%$ of $\mathrm{CeO}_{2}$ and $\mathrm{La}_{2} \mathrm{O}_{3}$. The gelling reaction was accomplished in $1 \mathrm{~h}$ under reflux at $70^{\circ} \mathrm{C}$ and in presence of distilled water and 2-buthanol, maintaining water to 2-buthanol molar ratio of 1:4. The obtained gels were dried in air at $110^{\circ} \mathrm{C}$ and calcined at $600^{\circ} \mathrm{C}$ for $6 \mathrm{~h}$. The potassium was impregnated with an aqueous $\mathrm{KNO}_{3}$ and dissolution dried at $100^{\circ} \mathrm{C}$; it was again calcined at $600^{\circ} \mathrm{C}$ for $4 \mathrm{~h}$. The potassium content was fixed in three $\mathrm{K}$ atoms per $\mathrm{nm}^{2}$ of support. Considering the similar specific area values of the mixed oxides, the $\mathrm{K}$ content was around to $9 \mathrm{wt} \%$ in the prepared catalysts.

\subsection{Characterization}

The calcined sol-gel mixed oxides and K-supported catalysts were characterized by means of AAS in a Perkin Elmer 3100 absorption spectrometer and $\mathrm{N}_{2}$ adsorption isotherms at $77 \mathrm{~K}$ using Micromeritics ASAP 2010 equipment. XRD was performed in a Rigaku diffractometer, using $\mathrm{CuK}_{\alpha}(\lambda=0.15406 \mathrm{~nm})$ as a radiation source and an Ni filter. For the TPR experiments, $0.500 \mathrm{~g}$ of the sample was reduced under an $\mathrm{H}_{2}$ flow up to $700^{\circ} \mathrm{C}$ in a Micromeritics TPR/TPD 2900 system equipped with a thermal-conductivity detector. Programmed thermal desorption profiles of $\mathrm{O}_{2}$ and $\mathrm{NH}_{3}$ were performed prior to cleaning the samples in He to a flow of $\mathrm{O}_{2}$ for $1 \mathrm{~h}$ at $700^{\circ} \mathrm{C}$ and then cooled at room temperature. After reaching room temperature, the desorption profile was detected at a heating rate of $10^{\circ} \mathrm{C} \cdot \mathrm{min}^{-1}$. The XPS measurements were performed in a VG Thermo Escalab 200R spectrometer equipped with an $\mathrm{MgK}_{\alpha}$ radiation source. Prior to the analysis, the samples were degasified at $300^{\circ} \mathrm{C}$ for $1 \mathrm{~h}$ in the spectrometer chamber. As reference, the peak of C1s occurred at $284.8 \mathrm{eV}$.

\subsection{Catalytic Activity}

The evaluation of the catalytic activity for soot combustion was studied using carbon black (CB) as the soot 
model. The catalyst and CB mixture for the assessment of the catalytic activity was prepared by mixing $4 \mathrm{mg}$ of CB and $16 \mathrm{mg}$ of catalyst in tight contact. The catalytic oxidation of the soot was conducted in a thermogravimetric apparatus (Netzch $409 \mathrm{PC}$ ) with $7.5 \mathrm{mg}$ of the mixture heated in a $180 \mathrm{~mL} \cdot \mathrm{min}^{-1}$ flow of $12 \% \mathrm{O}_{2} / \mathrm{He}$ at $10^{\circ} \mathrm{C} \cdot \mathrm{min}^{-1}$ up to $800^{\circ} \mathrm{C}$. The temperature at which combustion occurs at the maximum rate, denoted as $\mathrm{T}_{\mathrm{m}}$, was used as the measure of the catalytic activity. The stationary point method was used to calculate the apparent activation energy. Typically, samples of the catalysts and CB mixtures in tight contact were heated at four different heating rates in $180 \mathrm{~mL} \cdot \mathrm{min}^{-1}$ of $12 \% \mathrm{O}_{2} / \mathrm{He}$ in a thermogravimetric equipment.

\section{Results and Discussion}

\subsection{Specific Area}

The specific BET areas are summarized in Table 1. As expected, the sol-gel method generated materials with high surface area, which decreased when the alkali metal was added [24] [29]. Although the impregnation of 10 wt $\%$ of a metal could decrease the surface area of the support, the larger decreases illustrated in Table 1 were a consequence of the chemical behavior of potassium. Previous studies of this behavior indicate that, independent of the nature of support, the impregnation of potassium decreases the surface area over $50 \%$ of its total extent [24] [30]. The results of Table 1, corresponding to the reported effect, greatly decrease the $\mathrm{S}_{\mathrm{BET}}$ values for the $\mathrm{K} 5 \% \mathrm{La}_{2} \mathrm{O}_{3}-\mathrm{Al}_{2} \mathrm{O}_{3}$ catalyst, in which the area decreases to a value as low as $35 \mathrm{~m}^{2} \cdot \mathrm{g}^{-1}$, corresponding to $90 \%$ of the mixed oxide. In the other catalysts the decreases were approximately $85 \%$.

\subsection{XRD Diffraction}

The diffraction profiles of the mixed oxides and the K-supported catalysts are shown in Figure 1. At the top of Figure 1, the diffractograms correspond to the K-supported catalysts, and the bottom diffractograms correspond to the mixed oxides. It is seen that the addition of cerium or lanthanum precursor to the aluminum alkoxide during the gelation step leads to rather amorphous solids. Regarding to the $\mathrm{CeO}_{2}-\mathrm{Al}_{2} \mathrm{O}_{3}$ mixed oxides, the $\mathrm{CeO}_{2}$ (JPDF: 43-1002) phase is clearly identified, increasing with $\mathrm{CeO}_{2}$ loading. A different behavior is observed in the $\mathrm{La}_{2} \mathrm{O}_{3}-\mathrm{Al}_{2} \mathrm{O}_{3}$ counterparts, in which no diffraction peaks attributed to $\mathrm{La}_{2} \mathrm{O}_{3}$ (JPDF: 22-0369) are detected. The explanation relates to the previous reports where lanthanum species are inserted into the pore alumina or no diffraction is detected because the lanthanum species are highly dispersed in the amorphous phases [2]. Thus, the observed trend indicates that the lanthanum species inserted into the alumina lattice and the cerium is deposited as surface patches on the alumina. However, only for the $5 \mathrm{wt} \% \mathrm{La}_{2} \mathrm{O}_{3}-\mathrm{Al}_{2} \mathrm{O}_{3}$ is it possible to detect a diffraction line of $\mathrm{La}_{2} \mathrm{O}_{3}$, indicative that for $5 \mathrm{wt} \%$ of $\mathrm{La}_{2} \mathrm{O}_{3}$, the lanthanum species are well-dispersed and could form agglomerates. Table 1 displays the detected phases for the mixed oxides and the K-supported catalysts. Moreover, the similar diffractograms of the mixed oxides and the K-supported catalysts indicate a high thermal stability of the sol-gel mixed oxides. With regard to the K-supported catalysts, the K content of $\sim 9$ wt\% allows crystalline $\mathrm{K}$ species to be detected if they are in a low dispersion degree. No diffraction lines attributed to the $\mathrm{K}$

\section{Table 1. Surface area, pore volume, AAS K wt\% and detected XRD phases of the support and K-supported catalysts.}

\begin{tabular}{|c|c|c|c|c|c|c|c|}
\hline Catalyst & $\begin{array}{c}S_{B E T,}, \\
\mathrm{~m}^{2} \cdot \mathrm{g}^{-1}\end{array}$ & $\begin{array}{c}V_{\text {pore }} \\
\mathrm{cm}^{3} \cdot \mathrm{g}^{-1}\end{array}$ & $\begin{array}{c}K, \\
\mathrm{wt} \%\end{array}$ & \multicolumn{4}{|c|}{ Detected XRD phases } \\
\hline $3 \% \mathrm{CeO}_{2}-\mathrm{Al}_{2} \mathrm{O}_{3}$ & 502 & 0.26 & - & $\mathrm{CeO}_{2}$ & $\mathrm{Al}_{2} \mathrm{O}_{3}$ & - & - \\
\hline $5 \% \mathrm{CeO}_{2}-\mathrm{Al}_{2} \mathrm{O}_{3}$ & 475 & 0.40 & - & $\mathrm{CeO}_{2}$ & $\mathrm{Al}_{2} \mathrm{O}_{3}$ & - & - \\
\hline $3 \% \mathrm{La}_{2} \mathrm{O}_{3}-\mathrm{Al}_{2} \mathrm{O}_{3}$ & 486 & 0.53 & - & - & $\mathrm{Al}_{2} \mathrm{O}_{3}$ & - & - \\
\hline $5 \% \mathrm{La}_{2} \mathrm{O}_{3}-\mathrm{Al}_{2} \mathrm{O}_{3}$ & 490 & 0.06 & - & - & $\mathrm{Al}_{2} \mathrm{O}_{3}$ & - & - \\
\hline $\mathrm{K} / 3 \% \mathrm{CeO}_{2}-\mathrm{Al}_{2} \mathrm{O}_{3}$ & 69 & 0.17 & 9.2 & $\mathrm{CeO}_{2}$ & $\mathrm{Al}_{2} \mathrm{O}_{3}$ & - & - \\
\hline $\mathrm{K} / 5 \% \mathrm{CeO}_{2}-\mathrm{Al}_{2} \mathrm{O}_{3}$ & 156 & 0.26 & 9.1 & $\mathrm{CeO}_{2}$ & $\mathrm{Al}_{2} \mathrm{O}_{3}$ & - & - \\
\hline $\mathrm{K} / 3 \% \mathrm{La}_{2} \mathrm{O}_{3}-\mathrm{Al}_{2} \mathrm{O}_{3}$ & 116 & 0.35 & 9.2 & - & $\mathrm{Al}_{2} \mathrm{O}_{3}$ & - & - \\
\hline $\mathrm{K} / 5 \% \mathrm{La}_{2} \mathrm{O}_{3}-\mathrm{Al}_{2} \mathrm{O}_{3}$ & 35 & 0.04 & 9.0 & - & $\mathrm{Al}_{2} \mathrm{O}_{3}$ & $\mathrm{La}_{2} \mathrm{O}_{3}$ & $\mathrm{~K}_{2} \mathrm{O}$ \\
\hline
\end{tabular}

(-) indicates nothing was detected. 


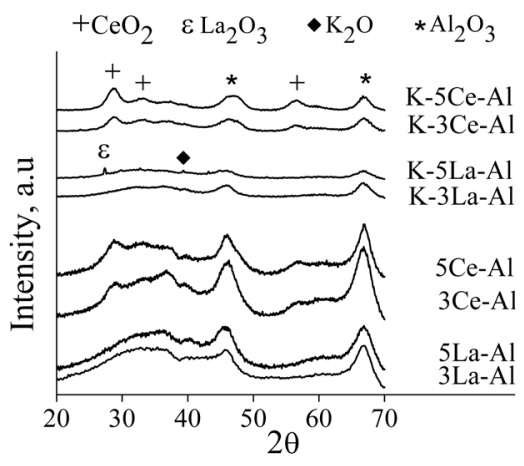

Figure 1. XRD spectra of the mixed oxides and K-supported catalysts.

species are detected, except for the larger $\mathrm{La}_{2} \mathrm{O}_{3}$ content in which only one diffraction line for a potassium species of $\mathrm{K}_{2} \mathrm{O}$ (JPDF:77-2151) is detected. This diffraction peak of $\mathrm{K}_{2} \mathrm{O}$ indicates lower potassium dispersion in this $\mathrm{K} / 5 \% \mathrm{La}_{2} \mathrm{O}_{3}-\mathrm{Al}_{2} \mathrm{O}_{3}$ catalyst.

\subsection{Temperature Programmed Reduction (TPR)}

Temperature-programmed reduction (TPR) profiles up to $700^{\circ} \mathrm{C}$ are shown in Figure 2. The similarity of the reduction profiles of each series is noticeable. The absence of the well-defined reduction peak of the mixed oxides indicates practically irreducible solids.

The non-reducible behavior of the mixed oxides used as support, attributable to the reduction peak at $\sim 500^{\circ} \mathrm{C}$, appear for the K-supported catalysts to the potassium species. Moreover, the large reduction peak of the Ksupported catalysts confirms the presence of potassium; although its presence was not detected by XRD because of its high dispersion degree. For better insight into the reduction behavior, the total H consumption in the TPR profiles between $400^{\circ} \mathrm{C}$ and $500^{\circ} \mathrm{C}$, which is a measure of the amount of $\mathrm{K}^{+}$species, is evaluated by deconvolution of the area under the curve using a Lorentzian peak, as shown in Table 2. The similar $\mathrm{H}$ consumption that corresponds to a $\sim 25 \%$ reduction indicates a similar amount of reduced potassium. It is proposed that the lower the reduction temperature, the lowest the K-mixed oxide interaction. Thus, for the $\mathrm{CeO}_{2}-\mathrm{Al}_{2} \mathrm{O}_{3}$ mixed oxides, the larger extent of cerium oxide as patches in $5 \% \mathrm{CeO}_{2}-\mathrm{Al}_{2} \mathrm{O}_{3}$ facilitate the alkali reduction at lower temperatures. The opposite effect is observed for the catalysts with lanthanum oxide, in which the reduction profiles indicate a reduction of the alkaline metal of the catalyst $\mathrm{K} / 3 \% \mathrm{La}_{2} \mathrm{O}_{3}-\mathrm{Al}_{2} \mathrm{O}_{3}$ at $511^{\circ} \mathrm{C}$, shifted towards higher temperatures; for $\mathrm{K} / 5 \% \mathrm{La}_{2} \mathrm{O}_{3}-\mathrm{Al}_{2} \mathrm{O}_{3}$, the catalyst presents the highest temperature of reduction.

\section{4. $\mathrm{O}_{2}$-Desorption Profile $\left(\mathrm{O}_{2}\right.$-DTP)}

Figure 3 displays the evolution of oxygen during the temperature-programmed desorption $\left(\mathrm{O}_{2}-\mathrm{TPD}\right)$ experiments, which is also closely related to the redox properties of the catalysts. The $\mathrm{O}_{2}$-TPD profiles of the mixed oxides are similar, indicating the large extent of desorbed oxygen, as expected because of their large number of hydroxyl groups. With regard to the K-supported catalysts, both series display similar desorption profiles, attributed to the alkali presence, and confirm the presence of highly dispersed K species. The TPD-MS experiments confirm that the evolved gas and the He flow only contain oxygen; therefore, the deconvolution of the oxygen desorption curves using the Lorentzian peak shapes allow the amount of the different desorbed oxygen species to be calculated. In Table 2, the amount of desorbed oxygen for the desorbed temperature is displayed. For the $\mathrm{La}_{2} \mathrm{O}_{3}-\mathrm{Al}_{2} \mathrm{O}_{3}$ series, there are clear larger increases of desorbed oxygen in the K-supported catalysts compared to the mixed oxides. This behavior indicates that potassium allows oxygen to be withheld and contributes to the formation of surface oxygen with deeper interactions with $\mathrm{K}$. For lower contents of $\mathrm{La}_{2} \mathrm{O}_{3}$, the oxygen is desorbed over $250^{\circ} \mathrm{C}$; however, for higher $\mathrm{La}_{2} \mathrm{O}_{3}$ content, the desorption temperature is displaced over $350^{\circ} \mathrm{C}$. This is in agreement with the results of TPR because at lower contents of $\mathrm{La}_{2} \mathrm{O}_{3}$, the potassium interacts with the support that allows for more oxygen desorption when compared to cerium catalysts. This corroborates the ease of $\mathrm{CeO}_{2}$ to retain oxygen. Previous works have established that the desorption peak lower $400^{\circ} \mathrm{C}$ are associated oxygen that is weakly bonded to the solid network [31]. Likewise, desorption at temperatures close to $500^{\circ} \mathrm{C}$ is 


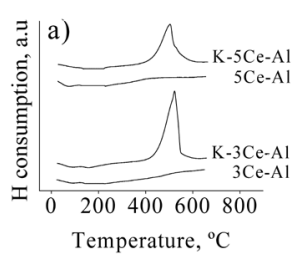

(a)

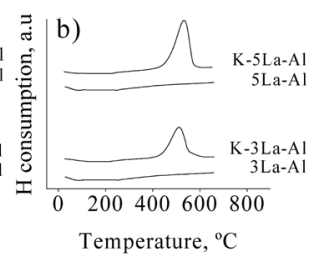

(b)

Figure 2. TPR profiles of the mixed oxides and K-supported catalysts.

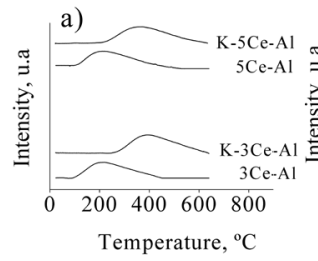

(a)

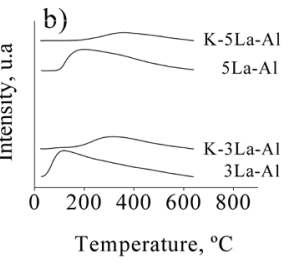

(b)

Figure 3. TPD- $\mathrm{O}_{2}$ profiles of the mixed oxides and K-supported catalysts.

Table 2. TPR and $\mathrm{O}_{2}$-DTP results for the support and K-supported catalysts.

\begin{tabular}{ccccc}
\hline Catalyst & $\begin{array}{c}\mathrm{T} \mathrm{red}, \\
{ }^{\circ} \mathrm{C}\end{array}$ & $\begin{array}{c}\mathrm{H} \text { consumption } \\
\mu \mathrm{mol} \cdot \mathrm{g}^{-1}\end{array}$ & $\begin{array}{c}\mathrm{T} \text { desorption, } \\
{ }^{\circ} \mathrm{C}\end{array}$ & $\begin{array}{c}\text { O desorbed } \\
\mu \mathrm{mol} \cdot \mathrm{g}^{-1}\end{array}$ \\
\hline $3 \% \mathrm{CeO}_{2}-\mathrm{Al}_{2} \mathrm{O}_{3}$ & $>600$ & 0 & 400 & 350 \\
$5 \% \mathrm{CeO}_{2}-\mathrm{Al}_{2} \mathrm{O}_{3}$ & $>600$ & 0 & 150 & 510 \\
$3 \% \mathrm{La}_{2} \mathrm{O}_{3}-\mathrm{Al}_{2} \mathrm{O}_{3}$ & $>600$ & 0 & 105 & 230 \\
$5 \% \mathrm{La}_{2} \mathrm{O}_{3}-\mathrm{Al}_{2} \mathrm{O}_{3}$ & $>600$ & 0 & 180 & 510 \\
$\mathrm{~K} / 3 \% \mathrm{CeO}_{2}-\mathrm{Al}_{2} \mathrm{O}_{3}$ & 522 & 530 & 385 & 520 \\
$\mathrm{~K} / 5 \% \mathrm{CeO}_{2}-\mathrm{Al}_{2} \mathrm{O}_{3}$ & 504 & 420 & 352 & 870 \\
$\mathrm{~K} / 3 \% \mathrm{La}_{2} \mathrm{O}_{3}-\mathrm{Al}_{2} \mathrm{O}_{3}$ & 511 & 450 & 320 & 361 \\
$\mathrm{~K} / 5 \% \mathrm{La}_{2} \mathrm{O}_{3}-\mathrm{Al}_{2} \mathrm{O}_{3}$ & 531 & 620 & & 690 \\
\hline
\end{tabular}

attributed to the strong oxygen bonds to the network [32]-[35]. Clearly, the incorporation of potassium allows oxygen to have more force than in solids without alkali. According to Table 2, the amount of desorbed oxygen is lower for the K-cerium catalysts.

\subsection{XPS analysis}

Table 3 compiles the respective binding energies (BE) of the core electrons of the elements. The C1s, O1s, Ce3d $\mathrm{d}_{5 / 2}, \mathrm{La}_{3} \mathrm{~d}_{5 / 2}$ and $\mathrm{K} \mathrm{2} \mathrm{p}_{3 / 2}$ core-level spectra were recorded for the K-supported catalysts. The C1s, O1s, $\mathrm{Ce}_{3} \mathrm{~d}_{5 / 2}, \mathrm{La}_{3} \mathrm{~d}_{5 / 2}$ and $\mathrm{K} \mathrm{2} \mathrm{p}_{3 / 2}$ core-level spectra were recorded for the K-supported catalysts. Figure 4 shows the spectra for one representative catalyst, the $\mathrm{K} / 5 \% \mathrm{La}_{2} \mathrm{O}_{3}-\mathrm{Al}_{2} \mathrm{O}_{3}$. The $\mathrm{C} 1$ s emission was used as reference. According to Praveen et al. [36] and Fleming et al. [37], the BE range of Ce between $875 \mathrm{eV}$ and $925 \mathrm{eV}$ indicates a mixture of surface $\mathrm{Ce}^{3+}$ and $\mathrm{Ce}^{4+}$. The obtained $\mathrm{BE}$ values of Table 3 of $\mathrm{Ce} 3 \mathrm{~d}_{5 / 2}$ at $883.0 \mathrm{eV}$ and Ce $3 \mathrm{~d}_{3 / 2}$ at 900 $\mathrm{eV}$ have a relationship with $13 \%$ and $12 \%$ of $\mathrm{Ce}^{3+}$ for the $\mathrm{K} / 3 \% \mathrm{CeO}_{2}-\mathrm{Al}_{2} \mathrm{O}_{3}$ and $\mathrm{K} / 5 \% \mathrm{CeO}_{2}-\mathrm{Al}_{2} \mathrm{O}_{3}$ catalysts, respectively. The presence of $\mathrm{Ce}^{3+}$, poorly appreciated, associated with the surface anion vacancies could be a consequence of the removal of oxygen during the sample pretreatment.

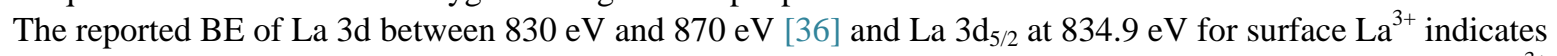
that the obtained values of 835.1 and $835.4 \mathrm{eV}$ shifted towards higher BE, indicating the presence of only La ${ }^{3+}$ 


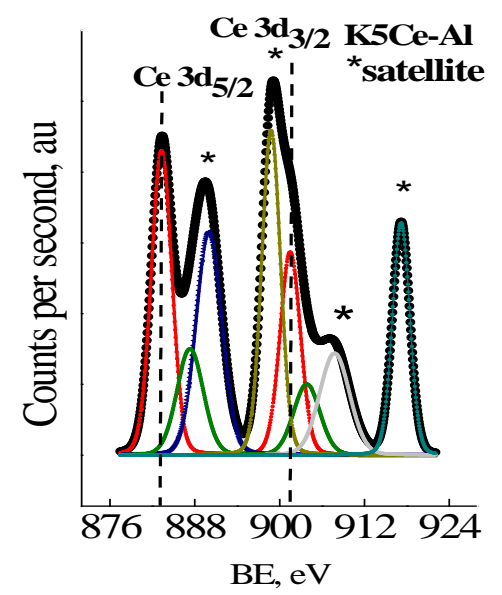

(a)

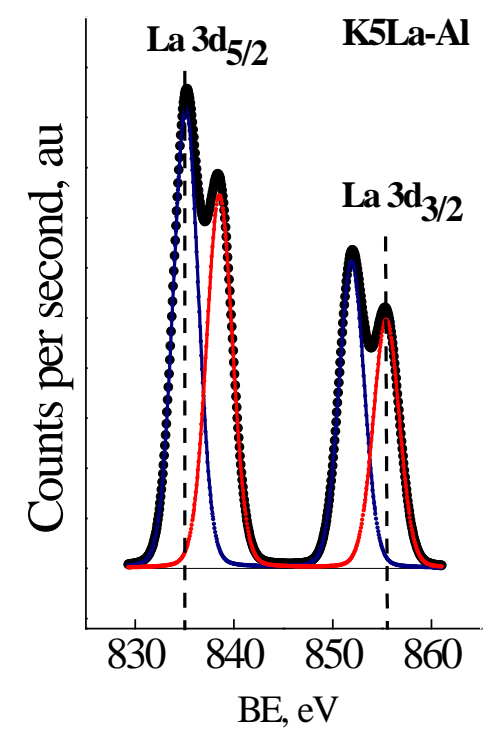

(c)

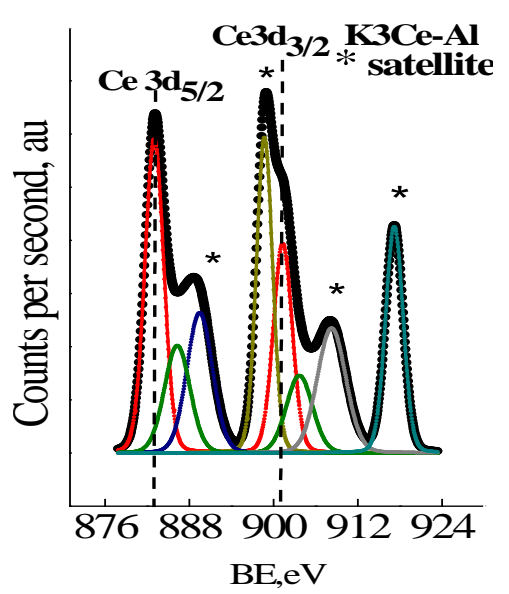

(b)

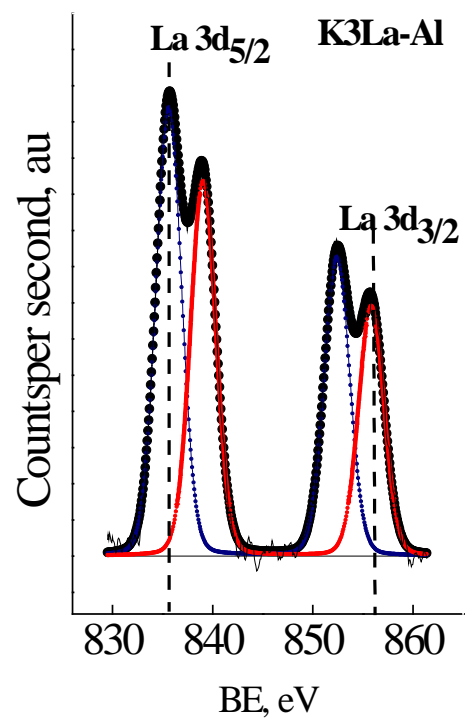

(d)

Figure 4. XPS data of the K-supported catalyst.

Table 3. Binding energies (eV) of the core levels for the K-supported catalysts.

\begin{tabular}{ccccc}
\hline Catalyst & $\mathrm{Ce} 3 \mathrm{~d}_{5 / 2}$ & $\mathrm{La} 3 \mathrm{~d}_{5 / 2}$ & $\mathrm{O} 1 \mathrm{~s}$ & $\mathrm{~K} \mathrm{2} \mathrm{p}_{3 / 2}$ \\
\hline $\mathrm{K} / 3 \% \mathrm{CeO}_{2}-\mathrm{Al}_{2} \mathrm{O}_{3}$ & $883.0(13)$ & ----- & 531.6 & 293.6 \\
$\mathrm{~K} / 5 \% \mathrm{CeO}_{2}-\mathrm{Al}_{2} \mathrm{O}_{3}$ & $883.1(12)$ & ----- & 531.7 & 293.8 \\
$\mathrm{~K} / 3 \% \mathrm{La}_{2} \mathrm{O}_{3}-\mathrm{Al}_{2} \mathrm{O}_{3}$ & ---- & 835.4 & 531.6 & 293.4 \\
$\mathrm{~K} / 5 \% \mathrm{La}_{2} \mathrm{O}_{3}-\mathrm{Al}_{2} \mathrm{O}_{3}$ & ----- & 835.1 & 531.5 & 292.8 \\
\hline
\end{tabular}

( ) mean percentage of $\mathrm{Ce}^{3+}$ over the surface catalyst

[38]. This is the expected result considering no other stable oxidation state of lanthanum occurs when combined with oxygen. Thus, the corresponding $\mathrm{BE}$ of lanthanum in the $\mathrm{La}_{2} \mathrm{O}_{3}-\mathrm{Al}_{2} \mathrm{O}_{3}$ mixed oxides indicates a $\mathrm{La}^{3+}$ cation is partially inserted into the alumina lattice leading to a strong La-O interaction [39]. The O1s BE at 531.5 to $531.7 \mathrm{eV}$ is associated with the weakly bonded surface species [32]. With regard to the surface $\mathrm{K}$ species, the $\mathrm{BE}$ at 293.4 to $293.8 \mathrm{eV}$ is indicative of potassium in a cationic chemical environment $\left(\mathrm{K} \delta^{+}\right)$[30], present in 3 wt $\% \mathrm{La}_{2} \mathrm{O}_{3}, 3 \mathrm{wt} \% \mathrm{CeO}_{2}$ and $5 \mathrm{wt} \% \mathrm{CeO}_{2}$ content of the $\mathrm{K}$ catalysts. A different behavior is detected for the 
$\mathrm{K} / 5 \% \mathrm{La}_{2} \mathrm{O}_{3}-\mathrm{Al}_{2} \mathrm{O}_{3}$, in which the $\mathrm{BE}$ decreases to $292.8 \mathrm{eV}$. This shift towards higher BE indicates more oxidized species, whereas the shifts towards lower $\mathrm{BE}$ are related with the surface deficit electronic density potassium species. According to the XRD spectra, the $\mathrm{K}_{2} \mathrm{O}$ detected appears as a cationic chemical environment $\left(\mathrm{K} \delta^{+}\right)$ when the potassium is similar to the $\mathrm{K}_{2} \mathrm{O}$ species [28].

Figure 5 and Figure 6 show the bulk and surface $\mathrm{Ce} / \mathrm{Al}, \mathrm{La} / \mathrm{Al}$ and $\mathrm{K} / \mathrm{Al}$ atomic ratios. It can be seen for both of the studied series that the higher surface values are indicative of the surface enrichment of Ce and La. Although, in the $\mathrm{K}$-supported on the $\mathrm{CeO}_{2}-\mathrm{Al}_{2} \mathrm{O}_{3}$ catalysts, the lower difference between the surface and bulk $\mathrm{Ce} / \mathrm{Al}$ indicates a lower dispersion of $\mathrm{CeO}_{2}$ on the $\mathrm{Al}_{2} \mathrm{O}_{3}$, easily detected by XRD. With regard to the $\mathrm{La} / \mathrm{Al}$, the larger differences between the surface and bulk values as well as the shifted of surface $\mathrm{La}^{3+}$ species support the hypothesis that surface $\mathrm{K} / 5 \% \mathrm{La}_{2} \mathrm{O}_{3}-\mathrm{Al}_{2} \mathrm{O}_{3}$ catalysts becomes La-enriched. Surface $\mathrm{K} / \mathrm{Al}$ ratios are lower than the bulk ratios for both series with similar values for each series. The higher surface $\mathrm{K} / \mathrm{Al}$ ratios for the $\mathrm{K} / \mathrm{CeO}_{2^{-}}$ $\mathrm{Al}_{2} \mathrm{O}_{3}$ catalysts indicate highly dispersed $\mathrm{K}$ species, in agreement with XRD. With regard to the $\mathrm{La}_{2} \mathrm{O}_{3}-\mathrm{Al}_{2} \mathrm{O}_{3}$ catalysts, the surface La-enrichment in the $\mathrm{K} / 5 \% \mathrm{La}_{2} \mathrm{O}_{3}-\mathrm{Al}_{2} \mathrm{O}_{3}$ catalyst by the larger inclusion of $\mathrm{La}^{3+}$ in the $\mathrm{Al}_{2} \mathrm{O}_{3}$ lattice may be the responsible for the presence of the $\mathrm{K}_{2} \mathrm{O}$ phase, detected by XRD, and the large $\mathrm{K}$ dispersion compared to the $\mathrm{K} / 3 \% \mathrm{La}_{2} \mathrm{O}_{3}-\mathrm{Al}_{2} \mathrm{O}_{3}$.

\subsection{Catalytic Activity}

Figure 7 shows the DTG curves for the CB combustion of the K-supported catalysts. The catalytic activity is related to the temperature corresponding to the maximum of the DTG curve $\left(T_{m}\right)$. Higher values of $T_{m}$ indicate lower catalytic activity. The $T_{m}$ values and the apparent activation energy $\left(E_{a c t}\right)$ of the mixed oxides and the $\mathrm{K}$-supported catalysts are summarized in Table 4 . The $\mathrm{T}_{\mathrm{m}}$ value for the uncatalyzed CB combustion was found to be $650^{\circ} \mathrm{C}$ (not shown), relatively the same value as the corresponding mixed oxides without the alkali active phase (not shown). Thus, the decreases at approximately $200^{\circ} \mathrm{C}$ in the $\mathrm{T}_{\mathrm{m}}$ values for the K-supported catalysts indicate the catalytic effect of the alkali. Although Figure 7 shows that there are no large differences in the Ksupported catalysts, the $10^{\circ} \mathrm{C}$ temperature decreases of the maximum reaction rate for the $\mathrm{K} / 5 \% \mathrm{La}_{2} \mathrm{O}_{3}-\mathrm{Al}_{2} \mathrm{O}_{3}$ catalysts can be explained considering the characterization results. Moreover, the apparent activation energy sup-

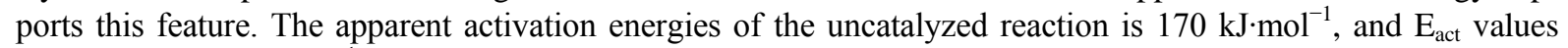
from 108 to $81 \mathrm{~kJ} \cdot \mathrm{mol}^{-1}$ have been reported for soot combustion with potassium-lanthanum cobaltite catalysts [40]. The $E_{\text {act }}$ of the mixed oxides is on the order of 137 to $145 \mathrm{~kJ} \cdot \mathrm{mol}^{-1}$, so it decreases to 92 and $81 \mathrm{~kJ} \cdot \mathrm{mol}^{-1}$
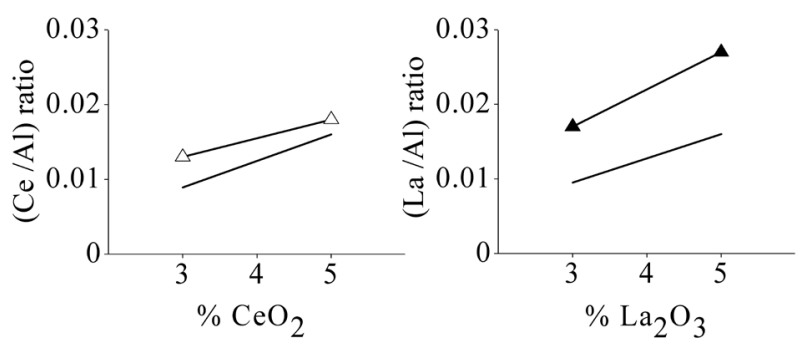

Figure 5. Atomic $\mathrm{Ce} / \mathrm{Al}$ and $\mathrm{La} / \mathrm{Al}$ ratios: (-) bulk; $(\Delta)$ cerium surface; ( $\boldsymbol{\Delta}$ ) lanthanum surface.
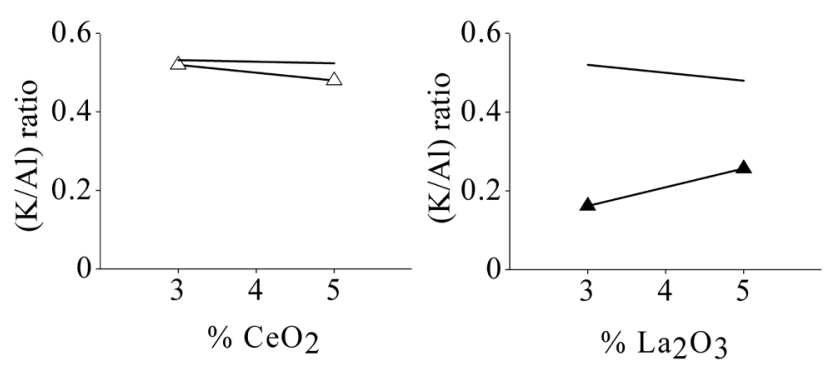

Figure 6. Atomic K/Al ratio: (-) bulk; $(\Delta)$ cerium surface; $(\boldsymbol{\Delta})$ lanthanum surface. 


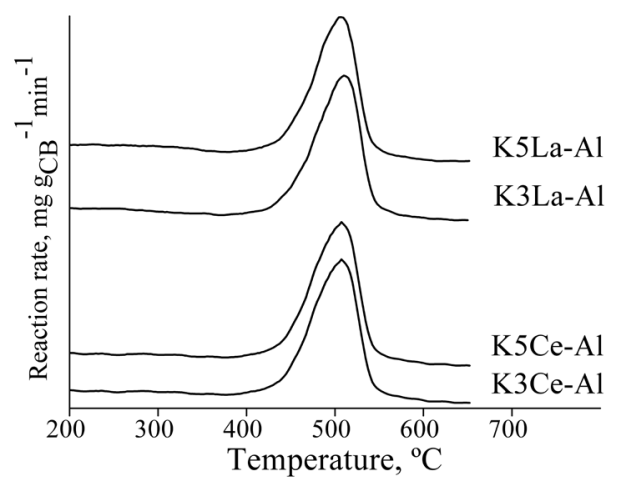

Figure 7. Curves of the carbon black combustion for the Ksupported catalysts.

Table 4. Temperature at the maximum combustion rate, Tm and apparent activation energy for the K-supported catalysts.

\begin{tabular}{ccc}
\hline Catalyst & $\mathrm{Tm},{ }^{\circ} \mathrm{C}$ & $\mathrm{E} \mathrm{act}^{\mathrm{kJ} \cdot \mathrm{mol}^{-1}}$ \\
\hline $\mathrm{K} / 3 \% \mathrm{CeO}_{2}-\mathrm{Al}_{2} \mathrm{O}_{3}$ & 480 & 81 \\
$\mathrm{~K} / 5 \% \mathrm{CeO}_{2}-\mathrm{Al}_{2} \mathrm{O}_{3}$ & 480 & 92 \\
$\mathrm{~K} / 3 \% \mathrm{La}_{2} \mathrm{O}_{3}-\mathrm{Al}_{2} \mathrm{O}_{3}$ & 480 & 92 \\
$\mathrm{~K} / 5 \% \mathrm{La}_{2} \mathrm{O}_{3}-\mathrm{Al}_{2} \mathrm{O}_{3}$ & 470 & 92 \\
\hline
\end{tabular}

for the K-supported catalysts; the larger decreases can be related to the redox and basic properties, favoring the oxygen activation on the catalyst surface.

\section{Conclusion}

The sol-gel method allows solids of high surface area to be obtained, thereby decreasing the area with the addition of potassium, which covers the pores of the material. The drastic effect is the most evident for the $\mathrm{K} / 5 \% \mathrm{La}_{2} \mathrm{O}_{3}-\mathrm{Al}_{2} \mathrm{O}_{3}$ catalyst. The effect of the incorporation of potassium increases its reducibility, decreases the surface area and allows having stronger oxygen in mixed oxides of a similar chemical nature. For $\mathrm{K}-\mathrm{La}_{2} \mathrm{O}_{3} \mathrm{cat}_{-}$ alysts, $\mathrm{La}_{2} \mathrm{O}_{3}$ enters into the alumina and promotes the availability of $\mathrm{K}_{2} \mathrm{O}$ in $\mathrm{K} / 5 \% \mathrm{La}_{2} \mathrm{O}_{3}-\mathrm{Al}_{2} \mathrm{O}_{3}$ with a chemical environment that favors its catalytic activity. However, for $\mathrm{K}-\mathrm{CeO}_{2}$ catalysts, the oxygen vacancies and mobility of these oxygen species for the catalytic activity in soot combustion reaction are crucial because the cerium oxide cannot enter the network. The characterization of the mixed oxides and K-supported catalysts confirms the importance of the use of potassium active phases as catalysts in soot combustion.

\section{Acknowledgements}

The authors would like to make special acknowledgements to FONDECYT, Grants 3150010 and 1130005 , and Red Doctoral REDOC, MINEDUC Project UCO1202.

\section{References}

[1] Müller, J.O., Su, D., Jentoft, R.E., Wild, U. and Schlögl, R. (2006) Diesel Engine Exhaust Emission: Oxidative Behavior and Microstructure of Black Smoke Soot Particulate. Environmental Science \& Technology, 40, 1231-1236. http://dx.doi.org/10.1021/es0512069

[2] Pecchi, G., Reyes, P., López, T. and Gómez, R. (2004) Pd-CeO ${ }_{2}$ and Pd- $\mathrm{La}_{2} \mathrm{O}_{3} /$ Alumina-Supported Catalysts: Their Effect on the Catalytic Combustion of Methane. Journal of Non Crystalline Solids, 345\&346, 624-627.

[3] Dai, F., Zhang, Y., Meng, M., Zhang, J., Zheng, L. and Hu, T. (2014) Enhanced Soot Combustion over Partially Substituted Hydrotalcite-Drived Mixed Oxide Catalysts CoMgAlLaO. Journal of Molecular Catalysis A: Chemical, 393, 68-74. http://dx.doi.org/10.1016/j.molcata.2014.05.031 
[4] Thevenin, P., Alcalde, A., Pettersson, L., Järas, S. and Fierro, J.L.G. (2003) Catalytic Combustion Of Methane over Cerium-Doped Palladium Catalysts. Journal of Catalysis, 215, 78-86. http://dx.doi.org/10.1016/S0021-9517(02)00146-X

[5] Ferrandon, M., Farrad, B., Björnbom, E., Klingstedt, F., Neyestanaki, A.K., Karhu, H. and Väyrynen, I.J. (2001) Copper Oxide-Platinum/Alumina Catalysts for Volatile Organic Compound and Carbon Monoxide Oxidation: Synergetic Effect of Cerium and Lanthanum. Journal of Catalysis, 202, 354-366. http://dx.doi.org/10.1006/jcat.2001.3303

[6] Kundakovic, Lj. and Flytzani-Stephanopoulos, M. (1998) Cu- and Ag-Modified Cerium Oxide Catalysts for Methane Oxidation. Journal of Catalysis, 179, 203-221.

[7] Pecchi, G., Cabrera, B., Buljan, A., Delgado, E.J., Gordon, A.L. and Jimenez, R. (2013) Catalytic Oxidation of Soot over Alkaline Niobates. Journal of Alloys and Compounds, 551, 255-261. http://dx.doi.org/10.1016/j.jallcom.2012.10.015

[8] Pecchi, G., Reyes, P., Jiliberto, M.G., López, T. and Fierro, J.L.G. (2006) Catalytic Combustion of Ethyl Acetate over Ceria-Promoted Platinum Supported on $\mathrm{Al}_{2} \mathrm{O}_{3}$ and $\mathrm{ZrO}_{2}$ Catalysts. Journal of Sol-Gel Science and Technology, 37, 169-174. http://dx.doi.org/10.1007/s10971-005-6623-0

[9] Pecchi, G., Cabrera, B., Delgado, E.J., García, X. and Jimenez, R. (2013) Activity of $\mathrm{KNbO}_{3}$ as Catalyst for Soot Combustion: Effect of the Preparation Method. Applied Catalysis A: General, 453, 341-348. http://dx.doi.org/10.1016/j.apcata.2012.12.030

[10] Jimenez, R., García, X. and Gordon, A.L. (2010) About the Active Phases of KNO 3 /MgO for Catalytic Soot Combustion. Reaction Kinetics, Mechanisms and Catalysis, 99, 281-287.

[11] Lox, E.S., Engler, B.H. and Koberstein, E. (1991) Diesel Emission Control. Studies in Surface Science and Catalysis, 71, 291-321. http://dx.doi.org/10.1016/S0167-2991(08)62985-7

[12] Ahlstrom, A.F. and Odenbrand, C.U.I. (1990) Combustion of Soot Deposits from Diesel Engines on Mixed Oxides of Vanadium Pentoxide and Cupric Oxide. Applied Catalysis, 60, 157-172. http://dx.doi.org/10.1016/S0166-9834(00)82179-X

[13] Fino, D., Fino, P., Saracco, G. and Specchia, V. (2003) Studies on Kinetics and Reactions Mechanism of $\mathrm{La}_{2-x} \mathrm{~K}_{x} \mathrm{Cu}_{1-y} \mathrm{~V}_{y} \mathrm{O}_{4}$ Layered Perovskites for the Combined Removal of Diesel Particulate and $\mathrm{NO}_{x}$. Applied Catalysis B: Environmental, 43, 243-259. http://dx.doi.org/10.1016/S0926-3373(02)00311-9

[14] Kureti, S., Weisweiler, W. and Hizbullah, K. (2003) Simultaneous Conversion of Nitrogen Oxides and Soot into Nitrogen and Carbon Dioxide over Iron Containing Oxide Catalysts in Diesel Exhaust Gas. Applied Catalysis B: Environmental, 43, 281-291. http://dx.doi.org/10.1016/S0926-3373(02)00325-9

[15] Rahayu, S., Monceaux, W.L., Taouk, B. and Courtine, P. (1995) Catalytic Combustion of Diesel Soot on Perovskite Type Oxides. Studies in Surface Science in Catalysis, 96, 563-574.

[16] Teraoka, Y., Nakano, K., Shangguan, W. and Kagawa, S. (1996) Simultaneous Catalytic Removal of Nitrogen Oxides and Diesel Soot Particulate over Perovskite-Related Oxides. Catalysis Today, 27, 107-113. http://dx.doi.org/10.1016/0920-5861(95)00177-8

[17] Fino, D., Russo, N., Saracco, G. and Specchia, V. (2003) The Role of Suprafacial Oxygen in Some Perovskites for the Catalytic Combustion of Soot. Journal of Catalysis, 217, 367-375. http://dx.doi.org/10.1016/S0021-9517(03)00143-X

[18] Shangguan, W., Teraoka, Y. and Kagawa, S. (1995) Effect of Oxide Composition of Spinel Type Cooper Chromites on the Catalytic Activity for the Simultaneous Removal $\mathrm{NO}_{\mathrm{x}}$ and Soot Particulate. Reports of the Faculty of Engineering, Nagasaki University, 25, 241-248.

[19] Uchisawa, J.O., Obuchi, A., Zhao, Z. and Kushiyama, S. (1998) Carbon Oxidation with Platinum Supported Catalysts. Applied Catalysis B: Environmental, 18, L183-L187. http://dx.doi.org/10.1016/S0926-3373(98)00046-0

[20] Oi-Uchisawa, J., Obuchi, A., Enomoto, R., Xu, J., Nanba, T. and Kushiyama, S. (2001) Oxidation of Carbon Black over Various Pt/MOx/SiC Catalysts. Applied Catalysis B: Environmental, 32, 257-268. http://dx.doi.org/10.1016/S0926-3373(01)00150-3

[21] Gross, M.S., Ulla, M.A. and Querini, C.A. (2009) Catalytic Oxidation of Diesel Soot: New Characterization and Kinetic Evidence Related to the Reaction Mechanism on $\mathrm{K} / \mathrm{CeO}_{2}$ Catalyst. Applied Catalysis A: General, 360, 81-88. http://dx.doi.org/10.1016/j.apcata.2009.03.011

[22] Zhang, Z., Mou, Z., Yu, P., Zhang, Y. and Ni, X. (2007) Diesel Soot Combustion on Potassium Promoted Hydrotalcite-Based Mixed Oxide Catalysts. Catalysis Communications, 8, 1621-1624. http://dx.doi.org/10.1016/j.catcom.2007.01.010

[23] Jimenez, R., García, X., Cellier, C., Ruiz, P. and Gordon, A.L. (2006) Soot Combustion with K/MgO as Catalyst. Applied Catalysis A: General, 297, 125-134. http://dx.doi.org/10.1016/j.apcata.2005.08.042

[24] Jimenez, R., Garcia, X., Lopez, T. and Gordon, A.L. (2008) Catalytic Combustion of Soot. Effects of Added Alkali 
Metals on CaO-MgO Physical Mixtures. Fuel Processing Technology, 89, 1160-1168. http://dx.doi.org/10.1016/j.fuproc.2008.05.013

[25] Liu, J., Zhao, Z., Chen, Y.S., Xu, C.M., Duan, A.J. and Jiang, G.Y. (2011) Different Valent Ions-Doped Cerium Oxides and Their Catalytic Performances for Soot Oxidation. Catalysis Today, 175, 117-123. http://dx.doi.org/10.1016/j.cattod.2011.05.023

[26] Li, Y., Gao, F., Kovarik, L., Peden, C.H.E. and Wang, Y. (2014) Effects of $\mathrm{CeO}_{2}$ Support Facets on $\mathrm{VOx} / \mathrm{CeO}{ }_{2}$ Catalysts in Oxidative Dehydrogenation of Methanol. Journal of Catalysis, 315, 15-24. http://dx.doi.org/10.1016/j.jcat.2014.04.013

[27] Campbell, C.T. and Peden, C.H.F. (2005) CHEMISTRY: Oxygen Vacancies and Catalysis on Ceria Surfaces. Science, 309, 713-714. http://dx.doi.org/10.1126/science.1113955

[28] Sawyer, R., Nesbitt, H.W. and Secco, R.A. (2012) High Resolution X-Ray Photoelectron Spectroscopy (XPS) Study of $\mathrm{K}_{2} \mathrm{O}-\mathrm{SiO}_{2}$ Glasses: Evidence for Three Types of $\mathrm{O}$ and at Least Two Types of Si. Journal of Non-Crystalline Solids, 358, 290-302. http://dx.doi.org/10.1016/j.jnoncrysol.2011.09.027

[29] Pecchi, G., Reyes, P., Zamora, R., López, T. and Gómez, R. (2005) Effect of the Promoter and Support on the Catalytic Activity of $\mathrm{PdCeO}_{2}$ - Supported Catalysts for $\mathrm{CH}_{4}$ Combustion. Journal of Chemical Technology \& Biotechnology, 80, 268-272. http://dx.doi.org/10.1002/jctb.1120

[30] Peralta, M.A., Milt, V.G., Cornaglia, L.M. and Querini, C.A. (2006) Stability of $\mathrm{Ba}, \mathrm{K} / \mathrm{CeO}_{2}$ Catalyst during Diesel Soot Combustion: Effect of Temperature, Water, and Sulfur Dioxide. Journal of Catalysis, 242, 118-130. http://dx.doi.org/10.1016/j.jcat.2006.05.025

[31] Mazumber, J. and de Lasa, H.I. (2014) Ni Catalysts for Steam Gasification of Biomass: Effect of La $_{2} \mathrm{O}_{3}$ Loading. Catalysis Today, 237, 100-110. http://dx.doi.org/10.1016/j.cattod.2014.02.015

[32] Dupin, J.C., Gonbeau, D., Vinatier, P. and Levasseur, A. (2000) Systematic XPS Studies of Metal Oxides, Hydroxides and Peroxides. Physical Chemistry Chemical Physics, 2, 1319-1324. http://dx.doi.org/10.1039/a908800h

[33] Merino, N.A., Barbero, B.P., Grange, P. and Cadús, L.E. (2005) LaCaCoO Perovskite-Type Oxides: Preparation, Characterisation, Stability, and Catalytic Potentiality for the Total Oxidation of Propane. Journal of Catalysis, 231, 232244. http://dx.doi.org/10.1016/j.jcat.2005.01.003

[34] Zhao, Z., Yang, X. and Wu, Y. (1996) Comparative Study of Nickel-Based Perovskite-Like Mixed Oxide Catalysts for Direct Decomposition of NO. Applied Catalysis B: Environmental, 8, 281-297. http://dx.doi.org/10.1016/0926-3373(95)00067-4

[35] Pecchi, G., Reyes, P., Zamora, R., Campos, C., Cadus, L.E. and Barbero, B. (2008) Effect of the Preparation Method on the Catalytic Activity of $\mathrm{La}_{1-x} \mathrm{Ca}_{x} \mathrm{FeO}_{3}$ Perovskite-Type Oxides. Catalysis Today, 133-135, 420-427. http://dx.doi.org/10.1016/j.cattod.2007.11.011

[36] Praveen, B.V.S., Cho, B.J., Park, J.G. and Ramanathan, S. (2015) Effect of La Doping of Ceria Abrasives for STI CMP. Materials Science Processing, 33, 161-168.

[37] Fleming, P., Ramirez, S., Holmes, J.D. and Morris, M.A. (2011) An XPS Study of the Oxidation of Reduced CeriaLanthana Nanocrystals. Chemical Physics Letters, 509, 51-57. http://dx.doi.org/10.1016/j.cplett.2011.04.090

[38] Sunding, M.F., Hadidi, K., Diplas, S., Lǿvvik, O.M., Norby, T.E. and Gunnǽs, A.E. (2011) XPS Characterisation of in Situ Treated Lanthanum Oxide and Hydroxide Using Tailored Charge Referencing and Peak Fitting Procedures. Journal of Electron Spectroscopy and Related Phenomena, 184, 399-409. http://dx.doi.org/10.1016/j.elspec.2011.04.002

[39] Haack, L.P., de Vries, J.E., Otto, K. and Chattha, M.S. (1992) Characterization of Lanthanum-Modified $\gamma$-Alumina by X-Ray Photoelectron Spectroscopy and Carbon Dioxide Absorption. Applied Catalysis A: General, 82, 199-214. http://dx.doi.org/10.1016/0926-860X(92)85005-V

[40] Pecchi, G., Dinamarca, R., Campos, C.M., García, X., Jimenez, R. and Fierro, J.L.G. (2014) Soot Oxidation on SilverSubstituted $\mathrm{LaMn}_{0.9} \mathrm{Co}_{0.1} \mathrm{O}_{3}$ Perovskites. Industrial \& Engineering Chemistry Research, 53, 10090-10096. http://dx.doi.org/10.1021/ie501277x 